\title{
ABSTRAK \\ UPAYA PENINGKATAN PENGETAHUAN MASYARAKAT MELALUI KEGIATAN PENYULUHAN KESEHATAN MENGENAI MENGENALI OBESITAS \& POTENSI PENYAKIT SERTA UPAYA PENGENDALIANNYA
}

\author{
Damanik, Chrisyen ${ }^{1 *}$, Sinaga, Sumiati ${ }^{2}$, Mukaromah, Siti $^{3}$ \\ Program Studi Ilmu Keperawatan, Institut Teknologi Kesehatan dan Sains Wiyata Husada Samarinda ${ }^{1,2,3}$ \\ *Korespondensi: Chrisyendamanik@stikeswhs.ac.id, sumiatisinaga@itkeswhs.ac.id
}

Obesitas adalah suatu penyakit serius yang dapat mengakibatkan masalah emosional dan sosial. Seorang dikatakan overweight bila berat badannya $10 \%$ sampai dengan $20 \%$ berat badan normal, sedangkan seseorang disebut obesitas apabila kelebihan berat badan mencapai lebih $20 \%$ dari berat normal. status kesehatan mayoritas masyakat RT 33 sebagian besar dalam kondisi kesehatan baik, namun terdapat beberapa dari masyarakat RT 09 yang menderita penyakit yang diantaranya Hipertensi, Berat Badan Berlebih sampai dengan Obesitas, Asam Urat, Gastritis, ISPA, Dislipedmia, gangguan jantung, stroke dan DM. Masyarkat RT 33 dengan tingkat Pendidikan yang rata-rata Pendidikan dalam kategori Atas dan memiliki penghasilan menengah atas, Masyarakat RT 33 memiliki pola kebiasaan hidup sehat yang dapat ditunjukkan melalui perilaku kebiasaan melaksanakan kegiatan olahraga rutin seperti senam sehat maupun jalan santai, dan masyakat memiliki kebiasaan menggunakan sarana layanan kesehatan seperti praktek dokter, klinik maupun rumah sakit yang memfasilitasi masyarakat dalam mengatasi dan mencegah setiap penyakit yang berkembang di masyarakat. Kegiatan yang dilaksanakan meliputi Penjajakan, Perneriksaan Kesehatan, Konseling \& Penyuluhan Kesehatan rnengenali Obesitas \& Potensi Penyakit Serta Upaya Pengendaliannya ditujukan pada warga RT 33 Kelurahan Air Putih Kota Samarinda. Sebanyak kurang lebih 26 peserta yang dilaksanakan pada tanggal 14 sampai 16 November 2019. Kegiatan pengabdian kepada masyarakat mendapatkan respon yang antusias dari warga masyarakat RT 33 Kelurahan Air Putih. Hasil Pemeriksaan kesehatan terdapat 15 orang masyarakat mengalami Berat Badan Berlebih, 6 diantaranya mendekat obesitas bahkan obesitas, 13 peserta mengalami peningkatan kadar kolesterol, dan terdapat 3 diantaranya warga mengalai berat badan berlebih dan terkena penyakit jantung dan DM.

KATA KUNCI: Penyuluhan Kesehatan, Obesitas, dan Pengabdian Masyarakat

\section{PENDAHULUAN}

Obesitas adalah suatu kondisi dimana perbandingan berat badan dan tinggi badan melebihi standar yang ditentukan. Obesitas merupakan peningkatan total lemak tubuh, yaitu apabila ditemukan kelebihan berat badan $>20 \%$ pada pria dan $25 \%$ pada Wanita karena lemak (Ganong, 2012). Dalam sepuluh tahun terakhir, obesitas menjadi masalah global (WHO,2015). Prevalensi obesitas didunia telah meningkat hamper dua kali lipat antara tahun 1980 dan 2008. Menurut data World Health Organization (WHO) tahun 2015, padatahun 2014 terdapat lebih dari 1,9 milyar orang dewasa diatas 18 tahun mengalami kelebihan berat tubuh dan lebih dari 600 juta orang mengalami obesitas (WHO, 2015).
Prevalensi kelebihan berat tubuh dan obesitas di negara-negara maju seperti Amerika, Eropa, dan Mediterania Timur telah mencapai tingkatan yang sangat tinggi. Kejadian ini tidak hanya terjadi di negara maju, kenaikan prevalensi kelebihan berat badan dan obesitas juga terjadi di negaranegara berkembang di Asia Tenggara dan Afrika (WHO, 2015). Kelebihan berat tubuh dan obesitas dapat menjadi faktor resiko penyakit karena gangguan metabolic seperti, penyakit jantung koroner, strok iskemiadan diabetes mellitus tipe 2 Kelebihan berat tubuh dan obesitas dapat menjadi factor resiko penyakit karena gangguan metabolic seperti, penyakit jantung koroner, stroke iskemia dan diabetes mellitus tipe 2 (WHO, 2015). 
Obesitas adalah suatu penyakit serius yang dapat mengakibatkan masalah emosional dan sosial. Seorang dikatakan overweight bila berat badannya $10 \%$ sampai dengan $20 \%$ berat badan normal, sedangkan seseorang disebut obesitas apabila kelebihan berat badan mencapai lebih $20 \%$ dari berat normal. Obesitas saat ini menjadi permasalahan dunia bahkan Organisasi Kesehatan Dunia (WHO) mendeklarasikan sebagai epidemic global (2016).

Berdasarkan fenomena tersebut perlu dilakukan kegiatan strategis berupa pengabdian kepada masyarakat dalam bentuk penyampaian informasi dalam upaya Mengenali Obesitas \& Potensi Penyakit Serta Upaya Pengendaliannya.

\section{METODE}

Kegiatan pengabdian kepada rnasyarakat di wilayah RT 33, kelurahan Air Putih, Kecarnatan Sarnarinda Ulu Kota Sarnarinda dilaksanakan pada tanggal 14 sarnpai 16 November 2019 berternpat di salah satu rurnah warga, sebanyak kurang lebih 26 mayarakat yang terlibat didalam kegiatan ini Kegiatan yang dilaksanakan rneliputi Penjajakan, Perneriksaan Kesehatan, Konseling \& Penyuluhan Kesehatan rnengenali Obesitas \& Potensi Penyakit Serta Upaya Pengendaliannya.

Kegiatan penyuluhan kesehatan rnengenai Upaya Peningkatan Pengetahuan Masyarakat Melalui Kegiatan Penyuluhan Kesehatan Mengenai Mengenali Obesitas \& Potensi Penyakit Serta Upaya Pengendaliannya yang baik dilakukan rnelalui tahapan sebagai berikut:

a. Kegiatan survei ternpat pengabdian kepada rnasyarakat yaitu di RT 33 Kelurahan Air Putih Kota Sarnarinda

b. Perrnohonan ijin kegiatan pengabdian kepada rnasyarakat kepada Lurah dan Ketua RT 33, Kepala Puskesrnas Air Putih, Kota Sarnarinda

c. Pengurusan adrninistrasi (surat-rnenyurat)

d. Persiapan alat dan bahan serta akornodasi e. Persiapan ternpat untuk Konseling dan Pendidikan kesehatan (penyuluhan) yaitu rnenggunakan salah satu Pendopo di RT 3 3 Kelurahan Air Putih Kota Sarnarinda.

Kegiatan Konseling \& pendidikan kesehatan (penyuluhan) rneliputi:

a. Pernbukaan dan perkenalan dengan rnasyarakat di wilayah RT 33 Kelurahan Air Putih Kota Sarnarinda yang rnenjadi sasaran kegiatan.

b. Penyuluhan mengenai "Upaya Peningkatan Pengetahuan Masyarakat Melalui Kegiatan Penyuluhan Kesehatan Mengenai Mengenali Obesitas \& Potensi Penyakit Serta Upaya Pengendaliannya".

c. Sesi diskusi/tanya jawab dengan peserta penyuluhan kesehatan rnengenai Mengenal Obesitas, Potensi Penyakit serta Pengendaliannya.

d. Sesi konseling secara berkelompok dengan 3 fasilitator yang intens mendengar dan menyampaikan terkait pengenalan berat badan berlebih bahkan obesitas, potensi masalah penyakit serta pengendaliannya

\section{HASIL}

Kegiatan Pemeriksaan Kesehatan dan pendidikan kesehatan (penyuluhan) tentang Upaya Peningkatan Pengetahuan Masyarakat Melalui Kegiatan Penyuluhan Kesehatan Mengenai Mengenali Obesitas \& Potensi Penyakit Serta Upaya Pengendaliannya berjalan lancar. Ketua RT bersama masyarakat sangat membantu mempersiapkan tempat dan mengkoordinir peserta pemeriksaan kesehatan dan penyuluhan. Peserta penyuluhan merupakan warga RT 33. Tempat yang dipakai untuk kegiatan tersebut adalah salah satu pendopo yang biasa digunakan untuk kegiatan di RT 33.

Sebelum melakukan kegiatan penyuluhan, maka terlebih dahulu diberikan kuesioner mengenai pemahaman terkait obesitas, penyebab dan potensi masalah penyakit yang bisa terjadi, selanjutnya 
pemateri memperkenalkan diri terlebih dahulu kemudian mencoba menggali pengetahuan dasar mengenai penyakit Obesitas. Pemateri mengajukan beberapa pertanyaan mengenai apa itu obesitas, apa yang diketahui terkait penyebab obesitas, masalah penyakit yang sering ditimbulkan serta upaya pencegahan? Bagaimana cara memilih dan mengelola diit tepat. Setelah menggali pengetahuan dasar kemudian pemateri mulai memaparkan materi pendidikan kesehatan mengenai upaya mengenali obseitas, potensi penyakit dan pengendaliannya.

Selama kegiatan penyuluhan berlangsung tampak peserta antusias dan memperhatikan isi materi penyuluhan. Kegiatan pemberian materi berlangsung selama kurang lebih 60 menit dan diakhir sesi pemateri memberikan kesempatan kepada peserta untuk mengajukan pertanyaan terkait materi yang telah disampaikan. Didapatkan 4 pertanyaan dari peserta penyuluhan terkait isi materi. Setelah menjawab pertanyaan dari peserta, pemateri melakukan evaluasi terkait pemberian materi yang telah disampaikan dengan cara memberikan pertanyaan dan memberikan kesempatan kepada peserta untuk menjawab pertanyaan tersebut. Peserta yang mampu menjawab pertanyaan mendapatkan door prize sebagai tanda apresiasi dan setelah itu kegiatan penyuluhan ditutup dengan kegiatan foto bersama antara pemateri, mahasiswa dan masyarakat RT 33 . Adapun kendala yang dijumpai selama proses kegiatan penyuluhan adalah pada hari pertama penyuluhan, kegiatan penyuluhan dilaksanakan didalam rumah yang langsung difasilitasi oleh ketua RT dan dokter Tenaga Kesehatan dari Puskesmas Air Putih, selama proses penyuluhan tidak ditemukan adanya hambatan, masyarakat sangat memperhatikan dan mendengar dan antusias selama kegiatan penyuluhan berlangsung.
Kegiatan pemeriksaan kesehatan, konseling dan penyuluhan mengenai Upaya Peningkatan Pengetahuan Masyarakat Melalui Kegiatan Penyuluhan Kesehatan Mengenai Mengenali Obesitas \& Potensi Penyakit Serta Upaya Pengendaliannya terlaksana dengan baik bahkan para peserta terlihat antusias dan mengharapkan kegiatan ini dapat berlanjut dengan pemberian materi yang lainnya terutama mengenalkan berbagai penyakit akibat obesitas dan upaya pencegahan yang dapat dilakukan oleh masyarakat serta penatalaksaan yang dapat dilakukan keluarga apabila ditemukan anggota keluarga yang mengalami berat badan berlebih atau obesitas.

Berdasarkan evaluasi dan monitoring yang dilakukan maka rekomendasi yang kami ajukan bagi kegiatan ini adalah:

1. Kegiatan serupa seharusnya dilaksanakan dan dikembangkan secara kontinyu untuk meningkatkan pengetahuan dan kewaspadaan masyarakat terutama mengenai penyakitakibat obesitas. Kegiatan dapat berupa pemeriksaan kesehatan berkelanjutan, konseling, upaya pencegahan melalui kegiatan olahraga Bersama, eek kadar lemak darah (kolesterol) secara rutin, mengkonsumsi makanan sesuai kebutuhan, penyuluhan secara berkelanjutan kepada masyarakat.

2. Diadakan kerjasama dengan terutama dengan Organiasi Profesi seperti Perhimpunan Perawat Jantung Indonesia dalam upaya keterlibatan lintas program dalam upaya pencegahan obesitas di masyarakat.

\section{KESIMPULAN}

Kegiatan pengabdian kepada masyarakat mendapatkan respon yang antusias dari warga masyarakat RT 33 Kelurahan Air Putih. Hasil Pemeriksaan kesehatan terdapat 15 orang masyarakat mengalami Berat Badan Berlebih, 6 diantaranya mendekat obesitas bahkan obesitas, 13 peserta mengalami peningkatan 
kadar kolesterol, dan terdapat 3 diantaranya warga mengalai berat badan berlebih dan terkena penyakit jantung dan DM. Diperoleh 4 pertanyaan dari peserta penyuluhan terkait materi penyuluhan dan masyarakat tersebut mengharapkan ada kegiatan serupa dapat dilanjutkan dan dikembangkan menjadi kegaiatan yang rutin di wilayah RT 33 .

\section{REFERENSI}

Dhianningtyas, Y., \& Hendrati, L. Y. (2006). Risiko Obesitas, kebiasaan rnerokok, dan konsurnsi gararn terhadap kejadian hipertensi pada usia produktif. The Indonesian Journal of Public Health, 2(3), 105109.

Joyce M. Black, Jane Hokanson Hawks. (2014) Keperawatan Bedah Manajemen Klinis untuk Hasil yang Diharapkan, Edisi 8.

Komeliani, K., \& Meida, D. (2012). Obesitas dan stress dengan kejadian hipertensi. KEMAS: Jurnal Kesehatan Masyarakat, 702), 117121.

Kurdanti, W., Suryani, I., Syarnsiatun, N. H., Siwi, L. P., Adityanti, M. M., Mustikaningsih, D., \& Sholihah, K. I. (2015). Faktor-faktor yang mempengaruhi kejadian obesitas pada rernaja. Jurnal Gizi Klinik Indonesia, I I (4), 179-190.

Widiantini, W., \& Tafal, Z. (2014). Aktivitas fisik, stres, dan obesitas pada pegawai negeri sipil. Kesmas: National Public Health Journal, 325-329. 